\title{
THE ASPECT OF CONFLICT BETWEEN PATERNALISM AND CONSTITUTIONALISM IN KOREAN CONTEMPORARY SOCIETY
}

\author{
Kyong-geun $\mathrm{OH}$, professor \\ Department of Korean Studies, \\ Institute of Linguistics, \\ Adam Mickiewicz University \\ al. Niepodległości 4 \\ 61-874 Poznań, Poland \\ okg615@gmail.com
}

\begin{abstract}
As of the 21st century, Koreans are struggling to achieve an advanced society. Material abundance may be a prerequisite for advanced society, but what is more important and essential is transparent and just society implementation in which an equal opportunity is given to all members of society and fair competition is ensured by fair rules. Unfortunately, in the Korean society, almost in all the layers of it, corruption and injustice/ immorality are still rampant.

I believe that such a phenomenon comes from the weak sense of the rule of law in Korean society compared with the other developed countries. Therefore, this paper considers the structure of consciousness of Koreans, which makes such things possible and makes it harder to eradicate, centered on Confucianism which emphasizes humanism or paternalism rather than the rule of law, and the mindset/ consciousness of Korean shamanism which does
\end{abstract}


not actively try to fight against evil.

Key words: paternalism, constitutionalism, Korean traditional society, Korean contemporary society, familism, communityism, Korean classical novel, Korean shamanism, Confucian political philosophy, the emotion of Korean han

\section{한국현대사회에서 온정주의와 법치주의의 갈등 양상}

논문초록: 21 세기 현재 한국인들은 선진사회로 도약하기 위해 몸부림치 고 있다. 물질적 풍요로움이 선진사회의 전제조건이 될 수도 있겠으나, 그에 우선하여 보다 중요하고 필수적인 것이 사회의 구성원 모두에 게 균등한 기회가 부여되고 공정한 룰에 의한 선의의 경쟁이 보장되는 투 명하고 정의로운 사회구현이다. 그러나 아쉽게도 한국사회에서는 정치, 경제, 교육 등 모든 분야에서 부정과 부패가 근절되지 않은 채 여전히 불 의가 기승을 부리고 있다.

필자는 그러한 현상이, 기존의 선진국가들과 비교할 때, 한국사회에서의 미흡한 법치 그리고 한국인들의 미약한 준법정신에서 비롯된다고 판단한다. 따라서 이 논문에서는 그러한 것들을 가능케하고 또한 쉽게 근절하기 어렵게 만드는 한국인의 의식구조를 법치주의보다는 인본주의 혹은 온정주의를 강조하는 유교, 그리고 악과의 투쟁을 적극적으로 시도하지 않는 무속의 의식구조를 중심으로 하여 고찰한다.

주제어: 온정주의, 법치주의, 한국의 전통사회, 한국의 현대사회, 가족주의, 공동체주의, 한국고전소설, 한국의 무교, 유교의 정치철학, 한국적 한의 정서.

\section{ASPEKTY KONFLIKTU MIĘDZY PATERNALIZMEM A KONSTYTUCJONALIZMEM WE WSPÓŁCZESNYM SPOŁECZEŃSTWIE KOREAŃSKIM}

Streszczenie: Koreańczycy wieku XXI dążą do stania się społeczeństwem zaawansowanym. Materialna obfitość może być warunkiem wstępnym dla rozwiniętego społeczeństwa, ale ważniejsze i bardziej istotne jest przejrzyste i sprawiedliwe wdrażanie społeczeństwa, w którym wszystkim członkom społeczeństwa zapewnia się równe szanse, a sprawiedliwa konkurencja zapewnia uczciwe zasady. Niestety, w społeczeństwie koreańskim, prawie we wszystkich jego warstwach, korupcja i niesprawiedliwość / niemoralność są wciąż nieokiełznane.

Uważam, że takie zjawisko wynika $\mathrm{z}$ słabego poczucia rządów prawa $\mathrm{W}$ społeczeństwie koreańskim $\mathrm{W}$ porównaniu $\mathrm{z}$ innymi krajami rozwiniętymi. Dlatego $\mathrm{w}$ tym artykule rozważa się strukturę świadomości 
Koreańczyków, która umożliwia to i sprawia, że trudniej jest wykorzenić takie podejście, skupiając się na konfucjanizmie, który kładzie nacisk na humanizm lub paternalizm, a nie na rządach prawa, oraz na mentalności/świadomości koreańskiego szamanizmu, który pasywnie podchodzi walki ze złem.

Słowa klucze: paternalism, konstytucjonalizm, tradycyjne społeczeństwo koreańskie, współczesne społeczeństwo koreańskie, rodzina, wspólnotowość, koreańska powieść klasyczna, szamanizm koreański, konfucjańska filolzofia polityczna, emocjonalność koreańskiego hanu

\section{What is the advanced society?}

\subsection{Democracy and capitalist society}

In various regions of the world, each race and nation has adapted to a particular environment and has developed its own distinctive society and culture. They have maintained their traditions and culture while promoting mutual development through various contacts and exchanges with neighboring peoples. However, with the rapid development of traffic and communication, the contacts and the exchanges have become increasingly easy for, and their scope has spread globally, so it is increasingly difficult to maintain the tradition and culture of your own. Moreover, since the West began to dominate the world from the modern times, their ideology and culture have also taken a leading position. Therefore, to date, the evaluation of a developed society (in the international society) is based on Western standards. In other words, it is a society based on the liberal democratic political system and the capitalist economic system established by the values of the Western world. Specifically, it is a society at the heart of which lie citizens, ensuring that all human beings can achieve realistic and universal values of life, namely that freedom and rights of individuals, equal treatment, private property, and the right to pursue happiness are guaranteed to the all its members.

In the development of history, the most notable change in human social life is the transfer from a communal life to a personal life. In the modern age it has accelerated, and now in the 21 st century 
even the existence of family, the minimum unit of community life, is threatened. For this reason, a modern society should ensure that its individual members can lead their lives based on fair laws and principles without any discrimination or restriction. This is because in a modern society it's becoming more and more difficult to expect help from their family members or other people, therefore they, as an independent individual, have to go through their life by themselves.

In the contemporary society, citizens are the central force of society. They have their rights as citizens, but are responsible for their actions at the same time. And we should remember that what a modern society demands from its members is not a sacrifice of their personal life to the community, nor the ideal morality and ethics, but an ordinary citizen with a common sense of morality and ethics that are generally accepted in the society.

\subsection{Fair and righteous society}

The fair and righteous society is a society that guarantees freedom and rights of individuals, equal treatment, and equality of opportunity, first of all, where justice applies fairly to everyone. It is a society of rule-of-law in which the justice and order are maintained by the law. The citizens have their right and opportunities based on the law while taking full responsibility for the consequences without any exceptions. Its prerequisites are, above all, fair application and enforcement of the law.

Ultimately, a developed society nowadays is a society, in which laws and principles are fairly applied to the all members without any preferences, privileges, and discriminations.

\subsection{Korean Modern Society and Status of Law}

Korean society is still a mixture of tradition and modernity. Of course, some elements of traditional society still have a positive effect on the lives of modern people, but it is also true that the others are acting as a stumbling block to achieving an advanced society which Koreans aspire to. We should remember here that the advanced society that Koreans aspire to is not their traditional society, but catching up with the developed countries of the West. It is the society of liberal 
democracy governed by the rule of law.

Then, it is already clear what the Koreans should do for it. Unfortunately, however, we can still find the ignorance of laws and principles by Koreans. The main cause of such behavior is the pursuit of excessive selfish interests only for themselves or for the groups to which they belong. In short, there is absence of the rule-of-law in Korean society, because people pursue only their own interests, regardless of all means and methods. The result is that corruption is rampant everywhere in the Korean society.

The absence of the rule of law in modern Korean society stems mainly from the blood ties, school ties/connections, nepotism, and regionalism, which are deeply rooted in Korean society from the past. The strong blood ties of Koreans are believed to have originated from the Confucian traditions, the most familyist religion in the world (Oh Kyong-geun 2013: 96-97). Families based on patriarchy demanded from their members the sacrifice of personal lives to the family by attaching importance to their reputation and honor in society. Therefore, Koreans should try to achieve success in the society for the benefit and honor of family more than for themselves as individuals. On the other hand, the people who were in poverty and suffered because of the oppression and exploitation by their rulers or foreign powers had to seek help only in their families and relatives. In other words, they inevitably had to reinforce the internal integrity among family members in order to fight for/ensure their survival and well-being in the struggle with the stronger and unjust forces from the outside which always exploited and oppressed them. The Confucian traditional way of thinking that emphasizes the interests and honor of the family, and the social conditions, in which an independent individual couldn't achieve his/her ideals or goals through fair competition has extended the unique and powerful familyism even in the modern Korean society. Unfortunately, such realistic thoughts and attitude of Koreans toward life have resulted in the absence of a lofty and higher dimensional world view of human life by concentrating only on pursuing realistic interests in their lives (Choi Jun-sik 2009: 179). Therefore, the collective egoism and the absence of the rule of law are still prevalent in Korean society.

The strong school ties and regionalism in Korea are an extension or an extended form of the selfish familism. Through their collective egoism the groups in power try to maintain or expand 
their profit and privilege, and those who lack of money and power to defend their lives against them. For both of them the more important thing is not the laws and principles that all citizens should obey, but a good relationship, in other words, loyalty and strong bonds among their members. Therefore, the neglect of responsibilities and obligations to society, the moral and ethical insensitivity, privileged consciousness, and corruption, especially by the people in power, are widespread in the Korean society.

The most serious problem in the Korean contemporary society is the absence of fair law enforcement. As we know, in such a society it is difficult to expect from citizens to voluntarily comply with the law. It is natural for them to ignore or disregard the law, insofar as there is widespread awareness like 'The law is only for the sake of others' or 'If you obey the law, you will lose'. It is impossible for Koreans to develop an advanced society, as long as there are groups with such collective selfishness pursuing only their own interests in a fraudulent way or justify their greed and misdeeds even in the name of the law. Therefore, so that the Korean society could become an advanced society, first of all, fair and thorough enforcement of laws should be made for all its members without any exceptions.

\section{Characteristics of Korean Traditional Society}

As mentioned above, the Korean society is still a mixture of tradition and modernity, and the negative elements of tradition still have a strong influence on modern Korean people. So, it is necessary to overcome or correct appropriately the negative aspects of the traditional society, because the advanced society of the West is the model of advanced society that Koreans want to achieve. Here, we should pay our special attention to the paternalism in Korean society. It is a result of the (too) emotional and humanistic thinking of Koreans based on the traditional concepts of reconciliation, harmony, and tolerance in human relations. And, it could be said that the fundamental source of it is also the Confucian ideology and its political philosophy, so a more detailed examination of it is necessary.

In the traditional Korean society Confucianism gave priority to community rather than individual, so the individuals had to 
sacrifice their life to the profit and social order of the community. In other words, the members of the community didn't have their personal freedom or legitimate rights like citizens in a modern society. The more serious thing is that it is not possible to maintain order by the law in a community centered on a familism. So, in the traditional Korean society, it was natural that the paternalism based on mutual trust, fraternity and a warm heart was the main method of maintaining order, because according to Confucian political philosophy a society and a nation are the extended forms of a family. Of course, it worked positively in the traditional society, but it's not suitable for the status of a citizen as an independent subject in modern society.

The political philosophy of Confucianism can be summarized as a government with a right and virtuous king (Yun Sa-sun 2010: 2021). In other words, the king was treated/ recognized as the father of the nation, so his political status was above the law. Based on the central power system centered on such a king, the provinces were ruled by the local officials sent by the king. But, although the king was a mighty power above the law, he had to try to make his people loyal to him and to keep the social order through his love and moral influence rather than the law as a physical force/ coercion. Rather than resorting to political power, the king had to rule by his own moral virtues as a noble and ideal man, that is so-called 'a government by means of his virtue' or 'government by a man, not by the law'. Confucian political philosophy is very familial, so the relationship between the ruler and the ruled was like the relationship between a father and a son based on mutual love and trust, morality and ethics (Geum Jang-tae 1991: 139-141). Therefore, for them the ideal society was the one in which a benevolent and sincere ideal leader rule and the people, impressed by the love of him, remain loyal to him and lead a moral and ethical daily life. It could be said that it is the most ideal society or country that humans can imagine. However, we should remember that such a society is only possible under the premise that each individual is a right person, first of all, properly educated and trained. As we can see, Confucian political philosophy demands an ideal value from human beings, and that is why it is too difficult to apply it to a modern civil society. It is almost impossible to demand from the ordinary citizens, especially in an anonymous modern society, to maintain the social order through their highly moral and ethical daily life. After all, what is the most desirable in a modern society is the law-abiding spirit of citizens rather than ethics 
or morality in daily life.

\section{Consciousness of Koreans about 'Evil and Revenge' based on Shamanism}

\subsection{Korean shamanism - Faith to seek good fortune}

Shamanism is the fundamental religion of Koreans, and since the beginning of the Korean nation to this day the shamanistic consciousness has been located in the center of their heart (Lee Gyutae 2000a: 5). Therefore, still shamanism prevails in the perception of the soul of Koreans, and is also a key element of the Korean culture (Min Yeong-hyeon 2003:130). According to Korean shamanism the most important thing for people is the life in this real world rather than in the afterlife. It means that a happy and blessed life in this world is more important than the salvation of the soul in the afterlife. Therefore, for Koreans the most important thing was their own or their family's well-being and prosperity. It is also evident in the ritual of Korean shamanism: "The believers in shamanism make their wish through the shamanistic
ritual, but it's scope is largely limited to one's own happiness, and
does not go beyond his own family. Therefore, it is said that, this is
nothing but an act of seeking a fortune for the sake of self-interest."
(Choi Jun-sik 2009: 90)

Of course, this is one of the reasons why Korean shamanism is criticized as a vulgar religion by modern people, because it is not interested in the social order or justice and the salvation of the soul afterlife. But, on the other hand, we should regard it as a reflection of the hard and painful life of Korean people in the history.

In the end, Korean shamanism is not very helpful

1 “무교를 신봉하는 사람들이 굿을 해서 비는 범위를 보면 대부분이 자신, 아니면 그 범위가 넓어 봐야 자기 가족을 넘어서지 못한다. 그러니 이것은 순전히 자기 이해만을 위하는 구복 행위에 불과하다는 것이다.” (최준식, 2009, 『무교 - 권력의 힘에 밀린 한국인의 근본신앙, 도서출판 모시는 사람들』, 90쪽). 
in the enforcement of justice and order in social communities that are beyond the scope of the family because it pursues the happiness and well-being of a small group centered on individuals, above all. Therefore, we need to look more in detail at the contradictory and fragile aspects of Korean shamanism in the struggle against evil, especially in the contemporary society, in terms of tackling corruption and thorough punishment for those who break the law.

\subsection{Korean shamanism - Faith based on the revengeful spirits}

First of all, Korean shamanism is the belief that a revengeful ghost attaches itself to a living person causing him illness or unhappiness. Therefore, Koreans are very reluctant to do things that cause resentment in others' minds. In other words, although they are harmed by others, they are passive in directly opposing or avenging them. It comes from the fear that through it they might be harmed. It was also greatly influenced by Korean shamanism. It can be understood by looking at how God is perceived in Korean shamanism.

As mentioned above, Korean shamanism's main belief is that a revengeful ghost attaches itself to a living person causing him/her all kinds of illness or unhappiness. And this also reflects the mindset of Koreans about God. Traditionally, they seek God when they are affected by unhappiness/misfortune, unlike the Western Christianity which demands to worship God even when life is smooth and happy. So, the reason Koreans go to a shaman is to find a way to solve their misfortunes rather than to get blessed by gods.

\footnotetext{
"The motives for Korean shamanistic rituals are usually to find ways to solve the misfortunes rather than actively seeking blessings of god." (Choi Gil-seong 1996: 133)
}

According to Korean shamanism, a person's resentment remains even after his/ her death. The soul of a person who died with a grudge cannot go to the world of spirits and becomes a ghost which wanders in the world of living people. Therefore, it is believed that the angry ghost causes unhappiness or sickness, attaching himself to a certain

\footnotetext{
2 “무속의례의 동기는 복을 받기 위하여 적극적으로 행하기보다는 탈이 나서 비로소 의례를 행하는 것이 일반적이다." (최길성, 『한국인의 한』, 133쪽).
} 
person to solve his/her grudge. Consequently, Koreans believed that all unhappiness in the life of a human being comes from the revengeful ghosts. And only a shaman providing the shamanistic ritual can prevent them from ruining their lives or cure illness caused by the revengeful ghosts. We can see them in more details through the process of Korean shamanism's ritual named Gut.

\subsection{The structure and purpose of Korean shamanistic ritual gut}

The basic/ general structure of Korean shamanistic ritual (gut) consists of the three stages: 1) inviting a god (청신, 請神), 2) treating well and appeasing it (오신, 娛神) in order to get from it the way/ method to solve people's problems, 3) sending it back to the world of spirits (송신, 䢪神) (Choi Jun-sik 2009: 60). In short, Koreans conducted a shamanistic ritual in order to make a friendly relationship between living people and revengeful ghosts which are harmful for people's life in this world.

\footnotetext{
"Korean shamanistic ritual is to offer sacrifices (food and alcohol) to a god/ ghost and to entertain/appease him through dancing and singing. In other words, a female shaman entertain/ appeases the ghost which brings misfortune to human beings." 3 (Choi Gilseong 1996: 131)
}

So, the Korean shamanistic ritual is to comfort the revengeful ghosts by serving them alcohol and food, singing and dancing. This reflects the mindset of the Korean people who believe that people should have good relationships with evil rather than fight against it. First of all, it is an expression of their self-instinct to avoid harm and their extremely realistic attitude toward life. Therefore, it is hard to find in Korean shamanism any profound world view of life and death, such as in other highly developed religions.

Also, what we need to pay more our attention to here is that the Koreans' attitude toward evil is ambivalent/indecisive. It means that, evil is divided into 'small' and 'big', and shamans having fear of the 'big evil' try to appease it, but when it comes to the 'small evil', they just despise it and expel it through simple gestures of threat. We

\footnotetext{
3 “굿은 신에게 제물을 바치고 가무로써 즐겁게 하는 성격이 강하다. 즉 무녀들이 탈이나기 쉬운 귀신을 모시는 의례가 굿이다." (최길성, 『한국인의 한』, 131쪽).
} 
can easily think that the shaman has to fight against 'big evil' more strongly, but in Korean shamanism he/she deals with it too passively. That's the weak point of Korean shamanism. And it is very similar to the Koreans' attitude and treatment, even in modern society, for those people who committed serious wrongdoings or large-scale corruption scandals, because they too easily forgive themselves and forget about them.

So, we can say that the extremely passive and self-defensive consciousness/attitude of Korean shamanism in fighting against evil still has a great influence on Koreans' modern daily life. And it is a big obstacle to the implementation of proper rule of law and social justice in the Korean modern society. Because there is no severe punishment for those who violate the law, they ignore the law, and this leads to a vicious cycle of committing criminal acts again and again.

\section{The emotion of Korean Han (恨)}

It is the emotion of Han that always appears when we discuss Korean traditional emotions. Therefore, it is said that Korean culture and Koreans themselves cannot be understood properly without understanding the emotion of Han. However, the emotion of Han is very unique and complex, so it is not easily understood even by Koreans, especially by foreigners.

'Han' is a lexically common emotion in China, Korea, and Japan. Generally, it is defined as a resentment, lament, remorse, and great sorrow (Cheon I-du 1985: 9). But here, we will talk about the unique Han that appears especially in the Korean culture and literature. It is defined, on the one hand, as compassion and sympathy for others and, on the other hand, as a strong will to achieve one's desires and dreams (Oh Kyong-geun 2013: 33-38).

First of all, Han of Koreans is introvert, not extrovert, it means that it is directed only toward the inside of Koreans' mind, not to the other people. In other words, they don't want to blame the other people who caused their misfortune and suffering, but try to overcome their negative feelings, like a grudge or resentment etc., in their mind by themselves. They call it as 'a process of sublimation of negative feelings'. In that way they try to regenerate themselves as a more 
mature human being. Therefore, "Korean Han is an act of sublimation of negative emotions which forgives, reconciles, and harmonizes with other people", (Min Yeong-hyeon 2006: 124).

And the process of overcoming and sublimating the negative emotions, such as anger and resentment etc., is known as an act of "fermentation of Han". Through it those negative emotions are constantly conquered/overcome, which results in their qualitative changes, namely they finally changed into positive emotions (Cheon Idu 1993: 108-109). It seems just like a sour and bitter alcohol at the beginning, becomes sweet and fragrant through the process of fermentation. So, it is called also as the Korean Han's function of 'creating a new value'. Koreans keep negative emotions in their mind and through the process of "fermentation of them" try to change them into positive emotions, because they believe that it is the way to become a more mature person.

Despite those positive aspects, the Korean Han is a significant obstacle to the implementation of the rule of law and justice in modern society. Because just/only suppressing and overcoming the resentment and grief etc. in the heart while tolerating and forgiving other people who caused those negative feelings is, we can say, the ethics of a helpless and incompetent person who is not able to counterattack or retaliate against the others who are stronger than he/she. So, from the point of struggle, it could be the logic of the weak people. That is why Han is criticized as Koreans' unique ideology of resignation, conformism, and defeatism. Of course, forgiveness and tolerance for those who commit wrongdoings are important, but a more important thing is that they at first should deeply regret their wrongdoings and take full responsibility for them.

There is another sentiment/ feeling of Korean people which, similar to Han, makes it impossible to properly press people to assume responsibility for their actions under the rule of law. That is the emotion of Jeong 정(情), and it is based mainly on compassion for others. Generally, it is still accepted positively by Koreans and called as the 'culture of Jeong'. According to it, even though someone has done something wrong, he/she should be tolerated and forgiven as a result of sympathy of other people rather than be punished by the law. As we know already, it's also one of the typical Korean

4 “한(恨)은 용서하고 화해하고 어우러지는 승화의 마음이다” (민영현, 2006 , 한국인의 삶과 한국학, 신지서원, 124 쪽). 
traditional consciousnesses which accentuate harmony in human relations, not hostility or punishment.

\section{The happy ending of the Korean classical novel}

The 'happy ending' is one of the characteristics of Korean classical novels, and is quite different from the tragedy in Western epic literature based on catharsis. This reflects the realistic world-centered thinking of Koreans. It means that for Koreans the life in this world is the most important thing. Life in this real world is difficult, hard, and sometimes very painful in both the East and the West. Therefore, it can be said that the Korean literature which makes such a happy ending is unrealistic, and the Western literature which portrays it tragically is realistic. However, it can be also said that the Korean classical novels are realistic, because they are frankly portraying the people's desire of having a comfortable, healthy and happy life in this real world rather than the salvation of soul or eternal life after death. Although good health and material affluence are fundamental to a happy life, a harmonious and amicable relationship with other people is also very important.

\footnotetext{
"The happy ending is confirmed as a general feature of Korean classical novels, which can be interpreted as a phenomenon formed in the sense of fear inherent in the consciousness of Koreans that a ghost with grudge is harmful to human beings, so they don't want have conflict with other people. The tragic ending is a creating a revengeful ghost, so it does not match with their fear for it. Therefore, it seems to be understood that the composition of the classic novel structure, a happy ending, is the result of Korean thinking/consciousness, which sav that 'Do not do harm to others, and if it was inevitable, you must solve it by yourself", (Seo Dae-seok 1978: 242).
}

\footnotetext{
5 “행복한 결말은 한국 고전소설의 일반적 특징임이 확인되며, 이것은 한국인의 의식에 내재된 원령작해(怨靈作害)로 인한 공포감과 그 공포감에서 유래된 원한 기피의 사고에서 형성된 현상으로 해석할 수 있다는 것이다. 비극적 결말이란 결국 원령(怨靈)의 존재를 만드는 것이기에 원령에 대한 공포감과 상치되는 것이다. 따라서 원억(寃憶)한 일을 만들지는 말고, 불가피하게 만들어졌다면 반드시 풀어버리는 우리 민족의 사고에서 행복한 결말이라는 고전소설 구성상의 도식은 이해될 수 있으리라고 본다.” (서대석, 1978, 「고전소설의 '행복한 결말' 과 한국인의 의식」, 『관악어문연구』 3집, 242쪽).
} 
That is why Koreans pursue harmony, reconciliation, tolerance and forgiveness. In addition, as we have seen above, Koreans tried to avoid antagonism and confrontation with others, because they have a belief that 'if you do harm to others, it comes back to you'.

Since Koreans knew that hatred and controversy with each other would only lead to a vicious cycle of revenge, the Korean classical literature and drama encouraged them to overcome their emotion of Han by forgiveness and reconciliation with each other through an exciting play that everyone can join.

"If we solve a grudge/ han through the 'sinmyeong', the serious trials and hardships can be overcome. In that case, there is no room for tragedy. Tragedy is not highly valued not only in Korean traditional play/drama, but also in other genres of Korean literature. [...] So, the happy ending of Korean classical novels should be understood in this way." (Jo Dong-il et al. 2005: 23-24).

Thus, 'happy ending' through forgiveness and reconciliation in the Korean classical novels and drama is composed of a structure in which not only the main character but also the negative characters are saved without exception:

\begin{abstract}
"Pansori seeks a reconciliation with other people, that is almost the same thing to the desire to reach a happy ending in Korean classical novels. The happy ending is that the positive hero gets salvaged, and is a reflection of the reconciliatory orientation. But in Pansori not only the positive main character but also the negative main character are guaranteed salvation. [...] It seems that the Koreans' mentality, which avoids making han/ grudge to other people went one step further, so they got to think that even the negative protagonist should not be made into a ghost with a grudge. The fact that so-called the 'motive of revenge' is not found not only in Pansori, but also in almost all the Korean narrative literature is to prove it."
\end{abstract}

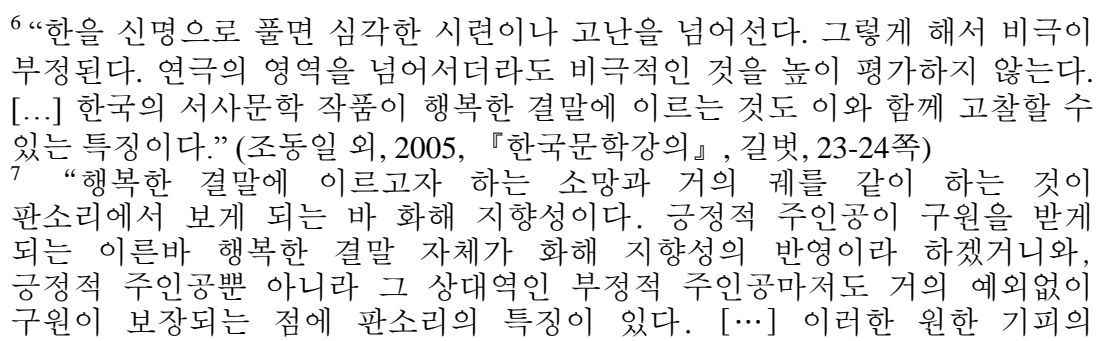


In conclusion, it can be seen that Korean classical novels and drama are aimed for an unified society where all people are harmonized through forgiveness and reconciliation rather than hatred, antagonism and conflict. This corresponds to the ideal society of Confucianism. However, it is difficult to expect it in an inhuman capitalist modern society, where the friendly human ties in the traditional society have become unfamiliar and personal interests are given the highest priority. Therefore, the maintenance of the justice and social order in the modern society should be relied on the rule of law rather than traditional paternalism.

\section{Rational fusion of tradition and modern}

The history of the Korean people as a weak nation of East Asia was a continuation of sufferings. In particular, in the first half of the 20th century, they lost their sovereignty as a nation under the Japanese colonial rule. After that, the nation was divided into two countries by the beginning of the global Cold War and the Korean war and, unfortunately, the biggest tragedy in the history of Korean people continues even in the 21 st century's globalization era.

Nevertheless, in the ruins of the fratricidal war, the Koreans worked hard with their unwavering will, and have achieved economic development that everyone in the world admires; furthermore, they finally developed a democratic society through a fierce struggle with the military dictatorship. Today, Koreans are proud of their economic and political achievements and are expanding their lives to the world. Now, Koreans are striving to achieve a world-class advanced society and country, and its accomplishment is ahead of them. Unfortunately, various corruption is still prevalent in the Korean modern society. The main causes of this are, as we have seen so far, as follows:

\footnotetext{
심리가 한걸음 더 나아가서 그 부정적 주인공도 원령으로 만들어서는 안 된다는 원한 기피 심리를 자아내게 한 것이라 하겠다. 판소리뿐 아니라 한국의 거의 모든 서사 문학에 있어서 이른바 복수의 모티프가 발견되지 않는 것도 이를 반증하는 것이라 하겠다.” (천이두, 1993, 『한의 구조 연구』, 문학과 지성사, 127쪽).
} 
1) Citizens do not trust the law because fair law enforcement has not been implemented properly,

2) Familyism and authoritarianism based on Confucian thought,

3) Too passive response to evil and the consciousness that is afraid of harming others based on Korean shamanism.

It is hard to expect the rule of law to be implemented properly in the Korean society as long as such a way of thinking is still prevalent: 'Law makes people rude', 'The law is far and the fist is close', 'If I observe the law, I will lose/If I observe the law, I will only pay for it' etc. In addition, a fair society cannot be achieved without overcoming the harmful effects of collective egoism such as nepotism, regionalism, and one's school ties/connections, namely the university one graduated from and the ties he/she has with other schoolmates. Therefore, Korean people must strongly resist the tyranny and deviant behavior of those who have power/authority and wealth. And also, must make sure that a thorough account of the responsibility of those, who violate social order and reasonable legal punishment for them should be done properly. We should keep in mind that tolerance and forgiveness with respect to them are possible only after their selfreflection and paying for their wrongdoings/misconduct since just tolerating and forgiving them is a stumbling block to achieving a fair and just modern society.

In conclusion, Korean people should remove the negative aspects of their tradition that do not match the life in a modern society and, on other hand, rationally and effectively merge their positive elements with modernity. That is the biggest challenge that Koreans have to face now to achieve an advanced society. It requires their wisdom, courage and action.

\section{References}

Cheon, I-du (천이두). 1985. 『한국문학과 한 hanguk munhak-gwa han』. 서울: 이우 출판사 (Seoul: I-u chulpansa).

Cheon, I-du (천이두). 1993. 『한의 구조 연구 Han-ui gujo yeongu』 . 서울: 문학과 지성사 (Seoul: Munhakgwa jiseongsa).

Choi, Gil-seong (최길성). 1996. 『한국인의 한 Hangugin-ui han』. 
서울: 예전사 (Seoul: Yejeonsa).

Choi, Jun-sik (최준식). 2009. 『무교 - 권력에 밀린 한국인의 근본 신앙 Mugyo - gwolleog-e millin Hangugin-ui geunbon sinang』. 서울: 도서출판 모시는사람들 (Seoul: Doseochulpan mosineun saram-deul).

Geum, Jang-tae (금장태). 1991. 『유교사상의 문제들 Yugyosasangui munje-deul』』. 서울: 려강 Seoul: Ryeogang.

Geum, Jang-tae (금장태). 2010. 『이념과 실현 - 한국유교의 과제 와 쟁점 Inyeom-gwa silhyeon - Hangug yugyo-ui gwaje-wa jaengjeom』. 서울: 지교 (Seoul: Jigyo).

Han, Do-hyeon (한도현) et al.. 2004. "유교의 예와 현대적 해석 Yugyo-ui ye-wa hyeondaejeok haeseok』. 서울: 청계 (Seoul: Cheongye).

Han, Ok-geun (한옥근). 2009. 『한국 전통극의 미학적 탐구 Hanguk jeontongeuk-ui mihakjeok tamgu』. 서울: 푸른사상 (Seoul: Pureun sasang).

Hangug jeongchi haghui/Hanguk sahui-haghui (한국정치학회/한국 사회학회). 2007. 『한국사회의 새로운 갈등과 국민통합 Hangug sahui-ui saeroun galdeng-gwa gugmin tonghab』. 서 울: 인간사랑 (Seoul: Ingan sarang).

Hanguk-sahui-haghui (한국사회학회). 2009. 『대한민국 60년의 사 회변동 - 성찰과 성과, 그리고 과제 Daehanminguk 60nyeon-ui sahui byeondong - seongchal-gwa seong-gwa, geurigo gwaje』. 고양: 인간사랑 (Goyang: Ingansarang).

Jeong, Chul-heon (정출헌). 2009. 『조선 최고의 예술 판소리 Joseon chwigo-ui yesul pansori』. 서울: 아이세움 (Seoul: Aiseum).

Jo, Dong-il (조동일). 1997. 『카타르시스 라사 신명풀이 - 연극영 화미학의 기본원리에 대한 생극론 해명 Katareusiseu rasa sinmyeongpuri - yeongeuk yeonghwa mihag-ui gibon weollie daehan saengeugnon haemyeong』. 서울: 지식산업사 (Seoul: Jisiksaneopsa).

Kim, Sang-ok. 1979. Han and classical literature, quoted in Kim Yong-suk, Study of women's literature in Joseon period. Seoul: Sookmyung Women's University.

Kim, Tae-gon. 1998. Korean Shamanism-Musism. Seul: Jimoondang. Kim, Yeol-gyu (김열규) et al.. 2001. 『 한국인의 죽음과 삶 Hangugin-ui jugeum-gwa sam』. 서울: 철학과현실사 (Seoul: Cheolhak-gwa hyeonsilsa).

Kim, Yeol-gyu (김열규). 1985. 『한국문학의 두 문제 - 원한과 가계 
Hangug munhak-ui du munje - wonhan-gwa gagye』. 서울: 학연사 (Seoul: Hagyeonsa).

Lee, Eun-bong (이은봉). 2000. 『한국인의 죽음관 Hangugin-ui jugeumgwan』. 서울: 서울대학교 출판부 (Seoul: Seoul Daehakyo chulpanbu).

Lee, Gyu-tae (이규태). 1980. 『한국인의 한 Hangugin-ui han』. 서 울: 세종출판사 (Seoul: Sejong Chulpansa).

Lee, Gyu-tae (이규태). 2000a. 『한국인의 샤머니즘 Hangugin-ui syameonijeum 』. 서울: 신원문화사 (Seoul: Sinweon Munhwasa).

Lee, Sang-ta (이상태), Yun Yong-sik (윤용식). 2006. 『고전소설론 Gojeon soseolnon』. 서울: 한국방송통신대학교출판부 (Seoul: Hangug Bangsong Tongsin Daehakyo Chulpanbu).

Lee, Young-hee. 2002. Ideology, Culture, and Han - Traditional and Early Modern Korean Women's Literature. Seoul: Jimoondang Publishing Company.

Min, Yeong-hyeon (민영현). 2006. 『한국인의 삶과 한국학 - 神仙 郎家를 꿈꾸며 Hangugin-ui sam-gwa Hangughak - sinseon nangareul ggumggumyeo』. 서울: 신지서원 (Seoul: Sinjiseowon).

Ryu, Seung-kuk (류승국). 2010. 『 유가철학과 동방사상 Yugacheolhag-gwa dongbang sasang』. 서울: 성균관대학교 동아시아학술원 (Seoul: Seonggyungwan Daehakyo Dongasia Hagsulwon).

Song, Yeong-bae (송영배). 2004. 『동서 철학의 교섭과 동서양 사 유 방식의 차이 Dongseo cheolhag-ui gyoseob-gwa dongseoyang sayu bangsik-ui cha-i 』 [Exchanges of Philosophical Ideas and the Difference of Thinking Mode between the East and the West]. 서울: 논형 (Seoul: nonhyeong).

Yun, Sa-sun (윤사순). 2010. 『조선, 도덕의 성찰 - 조선 시대 유학 의 도덕철학 Joseon, dodeok-ui seongchal - Joseon sidae yuhak-ui dodeokcheolhag』. 서울: 돌베개 (Seoul: Dolbegae). 